\title{
Population dynamics of Pseudomonas savastanoi pv. phaseolicola in bean, throughout the epiphytic and pathogenic phases
}

\author{
Abi Soares dos Anjos Marques ${ }^{(1)}$ and Régine Samson ${ }^{(2)}$ \\ (1)Embrapa Quarentena Vegetal, Parque Estação Biológica, s/noo, CEP 70770-901 Brasília, DF, Brazil. E-mail: abi.marques@embrapa.br \\ ${ }^{(2) I n s t i t u t ~ N a t i o n a l ~ d e ~ l a ~ R e c h e r c h e ~ A g r o n o m i q u e, ~ C e n t r e ~ A n g e r s-N a n t e s, ~} 42$ Rue Georges Morel, BP 60057, 49071 Beaucouzé Cedex, \\ France. E-mail: regine.samson@orange.fr
}

\begin{abstract}
The objective of this work was to monitor traits of the life cycle of Pseudomonas savastanoi pv. phaseolicola, in order to better understand the outbreak of bean halo blight, originating from a bacterial population in asymptomatic plants. Five experiments were conducted in the field, in greenhouses, and in humidity chambers. Changes in population size were evaluated in three field plantings, by introducing the bacteria in contamination focal points and observing the weather conditions favoring an outbreak. The dispersion of the bacteria in the field was followed by isolation and Bio-PCR analysis. Two assays were conducted in greenhouses and humidity chambers to evaluate the effect of leaf age on disease expression and the relationship between population level and number of leaf spots. The bacteria multiply intensively when in contact with a compatible host and reach high population sizes, with or without symptoms. The most favorable factor for bacterial multiplication and symptom triggering was water, and its role in the changeover from the epiphytic to the pathogenic phase might be linked to rainfall volume and intensity. Bacterial asymptomatic dispersion in the field is greater than disease emergence. In Brazil, the bacteria should be categorized as a present quarantine pest.
\end{abstract}

Index terms: Phaseolus vulgaris, Bio-PCR, epidemiology, halo blight, plant quarantine, weather conditions.

\section{Dinâmica populacional de Pseudomonas savastanoi pv. phaseolicola em feijoeiro, durante as fases epifítica e patogênica}

Resumo - O objetivo deste trabalho foi monitorar características do ciclo de vida de Pseudomonas savastanoi pv. phaseolicola, para melhor compreender a manifestação do crestamento aureolado do feijoeiro, originada de uma população bacteriana em plantas assintomáticas. Cinco experimentos foram conduzidos em campo, casas de vegetação e câmaras de cultura. Alterações no tamanho da população foram avaliadas em três plantios no campo, por meio da introdução da bactéria em focos de contaminação e da observação das condições climáticas que favoreceram a manifestação da doença. A dispersão da bactéria no campo foi acompanhada por isolamento e análise Bio-PCR. Dois ensaios foram conduzidos em casas de vegetação e câmaras de cultura, para avaliar o efeito da idade das folhas na expressão da doença e a relação entre o nível populacional e o número de manchas foliares. A bactéria multiplica-se intensamente logo que entra em contato com hospedeiro compatível e atinge níveis populacionais elevados, com a presença ou não de sintomas. $O$ fator que mais favoreceu a multiplicação bacteriana e o surgimento dos sintomas foi a água, e seu papel na passagem da fase epifítica à patogênica pode estar associado ao volume e à intensidade das chuvas. A dispersão não sintomática da bactéria no campo é maior que o aparecimento da doença. No Brasil, a bactéria deve ser categorizada como praga quarentenária presente.

Termos para indexação: Phaseolus vulgaris, Bio-PCR, epidemiologia, crestamento aureolado, quarentena vegetal, condições climáticas.

\section{Introduction}

Halo blight of bean (Phaseolus vulgaris L.), incited by Pseudomonas savastanoi pv. phaseolicola (Burk.) Gardan et al. 1992, is one of the most destructive diseases of this crop, causing yield losses as high as $45 \%$ for susceptible cultivars (Duncan et al., 2014). The disease was first described by Burkholder (1926) in the United States, and, since then, nine races of the pathogen have been reported. Due to its importance in a range of plant-microbe interactions, the bacteria have been raised from the status of a common pathogen to that of a study model (Arnold et al., 2011).

Typical symptoms of the disease can be detected over all the aerial parts of the bean plant. On cotyledons, the lesions are water soaked and round to irregular in 
shape; on leaves, they are yellowish/reddish-brown, equally water soaked, with a large light-green halo, and there may be curling and deformation of leaflets; on stems, lesions sometimes crack under the weight of pods and may cause bacterial ooze; and, on pods, the symptoms remain longer than on leaves, and seeds may be infected through their vascular system (Arnold et al., 2011).

The transmission of the bacteria occurs through seeds, as observed when the disease was first described, considering that bacterial cells can be located around the embryo and under the tegument. However, seeds do not always show symptoms, although white seeds, when infected, may show fluorescent areas under UV lights. Bacterial transmission from seeds to seedlings has shown an interesting inverse rate: $13 \%$, due to poor seed germination, from heavily infected seeds showing symptoms; $35 \%$, from a medium infected lot, with rare symptoms; and $52 \%$, from contaminated but asymptomatic seeds (Taylor et al., 1979).

The host range of $P$. savastanoi pv. phaseolicola is large but limited to the Phaseolae tribe of legumes, cultivated or spontaneous, including Phaseolus spp. ( $P$. vulgaris, $P$. coccineus, and $P$. lunatus); Vigna spp. ( $V$. radiata and $V$. unguiculata); and a series of weed and wild plant species, among which is the kudzu vine [Pueraria lobata (Willd.) Ohwi] (Lamichhane et al., 2015).

Halo blight of bean has spread worldwide through these hosts, occurring in more than 50 countries, over five continents. Its distribution is prevalent in temperate regions of the world, as well as in tropical highlands, such as the Andean region of South America and East Africa (Duncan et al., 2014). In Brazil, the bacteriosis was first reported in 1998, in the state of Paraná (Yorinori et al., 1998), which remains the sole record of its occurrence in the country. However, there has been no investigation regarding the reasons for the lack of spread, which could be linked to climatic factors or to aspects of the bacteria's life cycle, such as the epiphytic phase. When the bacteriosis was documented in Brazil, P. savastanoi pv. phaseolicola was categorized as a quarantine pest and was subjected to quarantine regulations, but then it was simply withdrawn from the quarantine pest list.

Even though the epidemiology of bean halo blight has sometimes been formally studied, it has been more frequently merely the object of observations, among them: that the disease shows a preference for cool climates and has been found in different temperate regions (Duncan et al., 2014); and that the transmission of the bacteria by seeds is the source of primary infections (Taylor et al., 1979), whereas rain splash and wind direction are the sources of secondary dispersion (Walker \& Patel, 1964). Lately, epidemiological studies have been linked to the bacterial genome, also examining how it is influenced by plant conditions and may affect plant response, such as resistance (Lovell et al., 2011). However, important aspects of the disease epidemiology, including critical factors affecting an outbreak or responsible for the bacteria changing from the epiphytic to the pathogenic phase, still need to be studied. In addition, the epiphytic life cycle of these bacteria has been observed, but rarely assessed.

The objective of this work was to describe traits of the life cycle of $P$. savastanoi pv. phaseolicola, in order to better understand the outbreak of the disease, originating from a bacterial population in asymptomatic plants.

\section{Materials and Methods}

Five experiments were carried out: the first, to follow the development of a $P$. savastanoi pv. phaseolicola population introduced into a bean field; the second, to evaluate the effect of leaf age on disease expression; the third, to understand the relationship between population level and number of leaf spots; the fourth, to evaluate weather conditions favoring an outbreak; and the fifth, to follow the dispersion of the bacteria and the disease in the field. The experiments were conducted in the field, in greenhouses, and in humidity chambers, between 1996 and 2000, in the department of Maine-et-Loire, in the region of Pays de la Loire, in France, during two growing seasons.

Five strains of $P$. savastanoi pv. phaseolicola were used in the present study, depending on the objective of the assay. To count the bacterial population, the following three spontaneous antibiotic-resistant mutants were used: CFBP 3634Rif2S and CFBP 3634Rif22, which were rifamycin resistant; and CFBP 3634Str, which was streptomycin resistant, to allow the use of a selective culture medium. For observation of symptoms, only two non-mutant strains were used: CFBP 4705 and CFBP 4847. All these strains were obtained from the Collection Française de Bactéries 
Associées aux Plantes (CFBP), in Angers, France. The strains were grown on yeast extract-peptone (YEP) culture medium, at $28^{\circ} \mathrm{C}$, for 48 hours; then were maintained on yeast extract-dextrose (YDC) culture medium covered with mineral oil; and archived at $-20^{\circ} \mathrm{C}$ in $20 \%$ glycerol. Bacterial suspensions were prepared and adjusted according to standard protocols (Schaad et al., 2001). To count the bacterial population, quantitative isolation was used, in which the plant part was crushed in $2.0 \mathrm{~mL}$ of water per gram of fresh weight, followed by decimal serial dilutions and plating of $100-\mu \mathrm{L}$ extract on solid modified sucrose peptone (MSP) culture medium (Schaad et al., 2001). Typical colonies were counted 48 hours after plating, as standard.

To analyze the behavior of the $P$. savastanoi pv. phaseolicola population introduced into the bean experimental field, a field of $1,260 \mathrm{~m}^{2}$ was divided into three plots, and each plot was divided into 99 miniplots of $1.4 \times 1.4 \mathrm{~m}$, with three rows of plants. In each plot, the central miniplot was the contamination focus. In plots I and II, the focus was established by introducing contaminated seedlings among existing plants. To obtain these seedlings, healthy seeds were pre-germinated using humid germinating paper at $26-28^{\circ} \mathrm{C}$ for 48 hours; then slightly wounded in the tegument, with a hypodermic syringe gauge; and immersed for $20 \mathrm{~min}$ in a $P$. savastanoi pv. phaseolicola suspension of $10^{8}$ CFU mL $\mathrm{mL}^{-1}$ of the CFBP 3634Rif2S strain. In plot III, the focus was established by hand spraying young

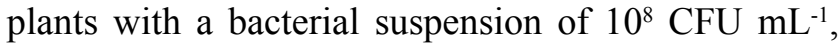
but using the CFBP 4705 strain. The field was irrigated with $10 \mathrm{~mm}$ water, once a week before flowering, and then with $30 \mathrm{~mm}$, unless it rained. Inoculated and neighboring plants were examined weekly during the crop cycle to observe the presence of symptoms. The bacterial population size, contained in one single leaf per rank, was determined at 10,18, 30, 42, and 66 days after inoculation, for plots I and II.

The experiment on the development of bean halo blight symptoms, as affected by leaf age at inoculation and by environmental humidity, was conducted in two steps. The first one was carried out in a greenhouse, using plants of the Michelet cultivar, inoculated at four different ages (8, 11, 14, and 18 days), by spraying cataphylls with a bacterial suspension of $3 \times 10^{5}$ CFU $\mathrm{mL}^{-1}$. Plants were covered with plastic bags, which had been previously moistened to simulate a moist chamber, for 48 hours after inoculation. Five replicates were established per treatment, and spraying with sterile water was used as control. The bacterial population on the cataphylls was counted twice: on the day of the inoculation and at the end of the assay.

The second step was performed in humidity chambers, using 12-day-old 'Michelet' plants, sprayed

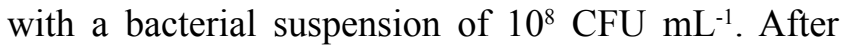
inoculation, plants were maintained at three different temperatures $\left(14,18\right.$, and $\left.22^{\circ} \mathrm{C}\right)$ and at a high humidity of $98 \%$, under intermittent mist, for $0,3,6$, and 21 hours. Subsequently, plants were placed in another chamber regulated to $23 / 21^{\circ} \mathrm{C}$ day/night, at $75 \%$ relative humidity, until the end of the experiment. In this assay, the bacterial population was also counted twice: on the day of the inoculation and at the end of the experiment, but on the first trifoliate leaf. Therefore, the number of spots per leaf was counted at 6,8 , and 10 days, as well as on the first trifoliate leaf. Five replicates of two plants were established per treatment, and spraying with sterile water was used as a control. The second step of the experiment, based on the results of the first one, aimed for a higher control of environmental conditions and also used a higher level of bacterial inoculum. In both cases, statistical analyses were performed using the software Stat-ITCF, version 5.0 (Institut Technique des Céréales et des Fourrages, Paris, France), and the means, subjected to the analysis of variance (Anova), were compared by Newman-Keuls' test, at $5 \%$ probability.

To determine the relationship between $P$. savastano $i$ pv. phaseolicola population size and number of foliar spots, tests were conducted in a humidity chamber, using 19-day-old 'Michelet' and 'Orlinel' plants, sprayed with a bacterial suspension of $10^{8} \mathrm{CFU} \mathrm{mL} \mathrm{mL}^{-1}$. After inoculation, plants were maintained at $26^{\circ} \mathrm{C}$, at a relative humidity of $80 / 100 \%$ (day/night). The number of spots per leaf was counted at 3, 7, and 17 days after inoculation; and the bacterial population was determined at the end of the assay, i.e., after the last counting of the number of spots. Three replicates of four plants each were established per treatment (cultivar), and control plants were sprayed with sterile water. The relationship between population size and number of foliar spots was analyzed by the regression analysis procedure, considering the two cultivars (Michelet and Orlinel) and leaf levels (first and the second trifoliate leaves) studied. 
In order to evaluate the development of bean halo blight primary infections, as affected by favorable weather conditions, an experiment was installed in the field, adopting seven weekly sowing dates as treatments. For this assay, seeds of the Canadian Wonder bean cultivar were artificially inoculated with the CFBP 3634Rif22 strain of $P$. savastanoi pv. phaseolicola, by immersion of seeds in a very concentrated bacterial suspension of $10^{9} \mathrm{CFU} \mathrm{mL}-1$, for $20 \mathrm{~min}$, immediately before sowing. An experimental plot of $170 \mathrm{~m}^{2}$ was divided into three other plots $(10 \times 15 \mathrm{~m})$, as replicates. Each plot had seven rows, with one row per sowing date. Every week, plants were examined for the presence of symptoms and the bacterial population was counted. Weather conditions were registered at a weather station.

To evaluate the spread of halo bean blight, an assay was carried out considering previously obtained information on bacterial dynamics from the epiphytic to the pathogenic phase. Two cultivars (Capitole and Masai) with different levels of susceptibility to $P$. savastanoi pv. phaseolicola were used, as well as the two following bacterial strains: CFBP 3634Rif22, which was used before; and CFBP 4847, revealed to be very aggressive through a previous pathogenicity test. In the experimental field, four $11.2 \times 14.0-\mathrm{m}$ plots were set up and divided into $1.4 \times 1.4-\mathrm{m}$ miniplots, with three rows of plants each. Two plots were sown with the Capitole cultivar, which is susceptible, and two with the Masai cultivar, which is tolerant. Central miniplots were the contamination focus, in which young plants were hand sprayed with a bacterial suspension of $10^{8}$ CFU $\mathrm{mL}^{-1}$. Watering was done using micro-sprinklers, and rainfall was registered when it occurred. Plants were examined weekly for the presence of symptoms and to detect the qualitative presence of bacteria by Bio-PCR (Schaad et al., 2007). Plot II, sown with the susceptible cultivar Capitole, inoculated with the CFBP 4847 strain, which is more aggressive, was chosen for analysis of disease dispersion.

\section{Results and Discussion}

The bacterial life cycle phase, known as epiphytic, has been observed for some decades and is present in numerous bacterial species (Marcuzzo, 2009). It is defined as the multiplication of bacteria on plant surfaces, including their host (Leben, 1965). For
P. savastanoi pv. phaseolicola, an epiphytic life phase in natural conditions was first reported by Legard \& Schwartz (1987) in volunteer bean plants.

In the present work, $P$. savastanoi pv. phaseolicola population dynamics was evaluated: in the field, in greenhouses, and in humidity chambers; on five different cultivars; in two growing seasons; and using five strains of the bacteria, including two rifamycin-resistant, one streptomycin-resistant, and two nonmutant. The epiphytic and pathogenic phases became evident for the species.

The population of $P$. savastanoi pv. phaseolicola introduced in the bean experimental field increased and dispersed through neighboring plants without causing symptoms. From the focus plot, the population level rose to $5 \times 10^{4} \mathrm{CFU}$ per plant in plot $\mathrm{I}$, in 17 days, and to $3 \times 10^{5} \mathrm{CFU}$ per plant in plot II, 30 days after inoculation. It is noteworthy that from 30 to 40 days after inoculation, the population decreased and increased again in the next 20 days after heavy rain, but without symptom appearance. A similar case was described for P. syringae pv. pisi by Hollaway et al. (2007), who observed that the bacteria survive, multiply, and spread epiphytically in pea (Pisum sativum L.) crops, and become pathogenic depending on weather conditions.

In the present study, significant differences were observed between initial and final populations of $P$. savastanoi pv. phaseolicola in cataphylls inoculated at four different ages $(8,11,14$, and 18 days), since there was an increase from $10^{5}$ to $10^{6}$ or $10^{7} \mathrm{CFU} \mathrm{g}{ }^{-1}$ cataphyll fresh weight. Although significant differences were not detected between ages, the most important multiplication took place in leaves inoculated at 8 days of age. It should be noted that no symptoms were identified in any of these treatments. The next step was to conduct an assay in precisely controlled conditions, using humidity chambers. Under controlled temperature conditions and high humidity, the disease caused pinhead-brown spots 6 days after inoculation, but no water-soaked lesions as previously observed. Temperature did not influence the number of spots, and, regarding wetting duration, two homogeneous groups were identified (Figure 1). The first group consisted of 6 and 21 hours of wetting, whereas the second consisted of 0 and 3 hours of wetting. It is known that young leaves are more susceptible to $P$. savastanoi $\mathrm{pv}$. phaseolicola and to $P$. savastanoi $\mathrm{pv}$. savastanoi at any 
age of the plant (Jacques, 1996). It seems that among the highlighted abiotic factors, water plays a key role in symptom expression. This is in accordance with the results described by Mabagala \& Saettler (1992), who compared disease intensity between bean grown alone and in association with corn (Zea mays L.). These authors observed a bacterial population that was 100 -fold larger in the intercropping system, in which bean leaves took $40 \%$ more time to dry. Pauwelyn et al. (2011) reported the same effect for Pseudomonas cichorii, when the use of surface drip irrigation, instead of overhead sprinklers, caused the reduction of midrib rot incidence.

The relationship between $P$. savastanoi pv. phaseolicola population size and the number of foliar spots on bean was analyzed by the regression analysis procedure, considering the two cultivars (Capitole and Masai) and the two leaf levels (first and second trifoliate leaves) evaluated. No linear correlation was found between these parameters, indicating once more that bean leaves may support high bacterial population sizes in an asymptomatic way. These results are contrary to those obtained for Xanthomonas axonopodis pv.

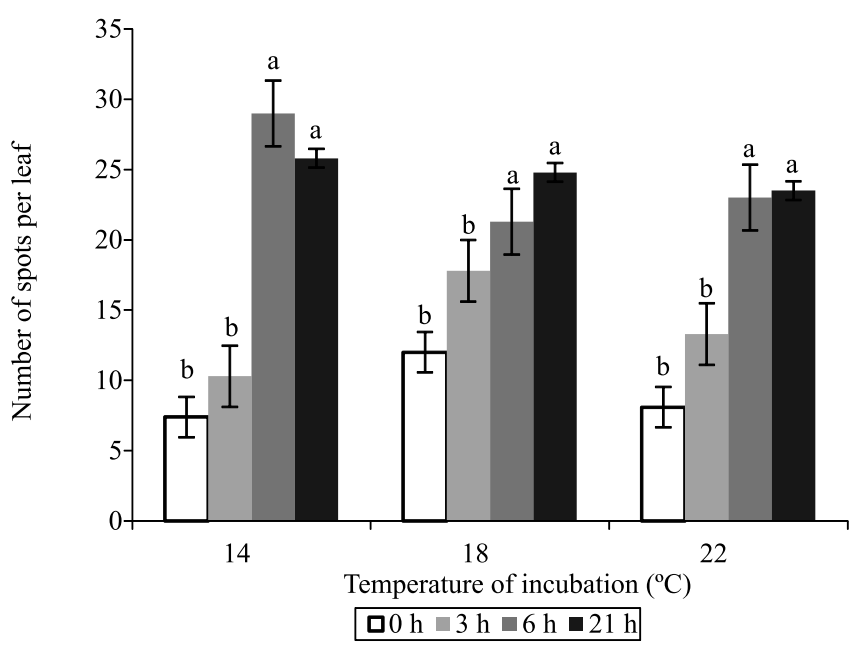

Figure 1. Number of spots (mean of 10 plants) on first trifoliate leaves (TL1) of the Michelet bean (Phaseolus vulgaris) cultivar, 10 days after inoculation with Pseudomonas savastanoi pv. phaseolicola, at $10^{8} \mathrm{CFU} \mathrm{mL}^{-1}$, in humidity chambers, as affected by post-inoculation conditions, i.e., incubation temperature $\left(14,18\right.$, and $\left.22^{\circ} \mathrm{C}\right)$ and wetting duration ( $0,3,6$, and 21 hours). Lowercase letters indicate significant differences in wetting duration at the same incubation temperature by Newman-Keuls' test, at $5 \%$ probability. phaseoli, when a significant positive correlation was observed between epiphytic population size and bean common bacterial blight severity in both overhead and furrow-irrigated fields (Akhavan et al., 2013).

According to sowing dates, the bacterial population evolves differently, as shown by counting at 21 and 28 days after sowing. A significant linear correlation was found between population size and rainfall sum $(\mathrm{R}=0.87)$, and a weaker correlation with temperature sum $(R=0.68)$. Disease symptoms were detected in all plants at different ages, simultaneously, just after 2 days of heavy rain and always on the youngest leaves. These symptoms were more pronounced on the last sowing date, in which plants had barely emerged from the soil when the rainfall event took place (Figure 2). Diseased plants represented $33.7 \%$ of the population at that seventh sowing date, but decreased to 5.6, 4.1, and $0.4 \%$ at the sixth, fifth, and fourth sowing dates, respectively. Moreover, a polynomial regression gave a good correlation between rainfall sum for the first 10 days after sowing and total percentage of diseased plants for all sowing dates, with $\mathrm{R}=0.86$. Apparently, bacteria start multiplying at seed sowing and foliar spots appear right after heavy rain, inducing infection. The effect of rain on the frequency of plant infection has also been described for bean bacterial wilt due to

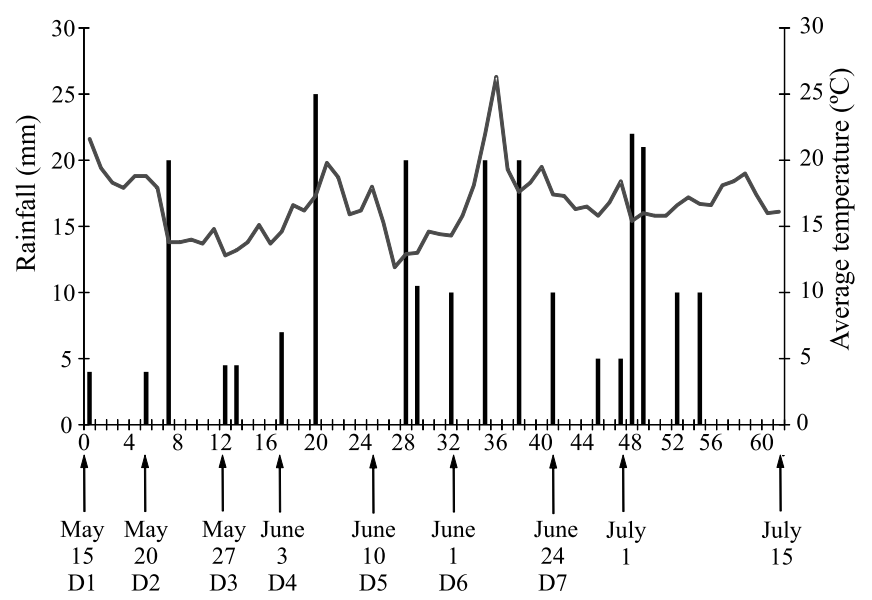

Figure 2. Weather conditions registered at a weather station during the experiment, in order to evaluate those favoring an outbreak of halo blight of bean (Phaseolus vulgaris). D1 to D7, sowing dates of 'Canadian Wonder' bean seeds artificially inoculated with the CFBP 3634Rif2S strain of Pseudomonas savastanoi pv. phaseolicola, at a suspension of $10^{9} \mathrm{CFU} \mathrm{mL} \mathrm{m}^{-1}$, immediately before sowing.

Pesq. agropec. bras., Brasília, v.51, n.5, p.623-630, maio. 2016 DOI: $10.1590 / \mathrm{S} 0100-204 \mathrm{X} 2016000500024$ 
Curtobacterium flaccumfaciens pv. flaccumfaciens (Harveson et al., 2015), when it was found that storms and hail events that caused physical damage to bean plants enhanced the disease, by favoring stomatal opening or bypassing plant defense by creating wounds as entry sites. The effect of rainfall on populations of $P$. syringae pv. tomato on tomato (Solanum lycopersicum L.) plants was determined by a rain simulator, showing that epiphytic populations are affected by rain events depending on the diameter of the rain drops, and, that, when the host-pathogen relation was already established, high rain intensity increased bacterial growth (Pietrarelli et al., 2006). Although it is essential to have open stomata for bacterial penetration, Melotto et al. (2008) argue that these surface openings may play an active role in limiting bacterial invasion, as part of the plant's innate immune system (Baker et al., 2010). In addition, it was observed that symptoms appeared with a bacterial population no less than $10^{5} \mathrm{CFU}$ per leaf, which leads to the quorum-sensing phenomenon (Yoshida et al., 2006). A regulator system has been studied inside $P$. syringae, which allows the bacteria to respond to environmental changes (Deng et al., 2015).

The susceptible Capitole cultivar, sown in the central miniplot and inoculated with the more aggressive CFBP 4847 strain, received $43 \mathrm{~mm}$ of irrigation and showed typical disease symptoms 10 days after inoculation. Symptoms were 1.0 - to $2.0-\mathrm{mm}$ water-soaked lesions surrounded by a large light-green halo. One month after inoculation, during the last survey, that miniplot showed $100 \%$ diseased plants. Two other focus miniplots - 'Capitole' inoculated with the CFBP 3634Rif2S strain, and 'Masai', with the CFBP 4847 strain - had 7 and $18 \%$ diseased plants, respectively. One focus plot ('Masai' inoculated with the CFBP 3634Rif2S strain) did not the present disease, despite maintaining a bacterial population until the end of the experiment.

The next step was to assess the spreading of the disease and the bacteria around the central focus miniplot. The more highly-contaminated miniplot was chosen for analysis, i.e., plot II of the Capitole cultivar inoculated with the CFBP 4787 strain. Diseased plants appeared in three miniplots near the focus, whereas bacteria were detected in all eight miniplots around the focus and also in the ten miniplots in the second ring of miniplots around the focus. After 1 month, the disease had dispersed 1.8 times the focus surface (1.4 linear meter), whereas the bacteria had dispersed 5.4 times (2.8 linear meters) (Figure 3). This is not a large distance, considering the dispersion reported by Walker \& Patel (1964), of 26 to $60 \mathrm{~m}$ for the same disease; however, during the experimental period, there was a very heavy rainfall of $125 \mathrm{~mm}$ in one day, which may explain the different results. Beattie (2011) considers that water is a limited resource in aerial plant tissues and is subject to manipulation by both plant and pathogens, leading to a new interaction model, in which plants promote desiccation at the infection site in order to restrict pathogen growth, as one component of defense, and foliar pathogens manipulate water relations, as one component of pathogenesis.

Despite the fact that P. savastanoi pv. phaseolicola has not dispersed in Brazil since its first occurrence

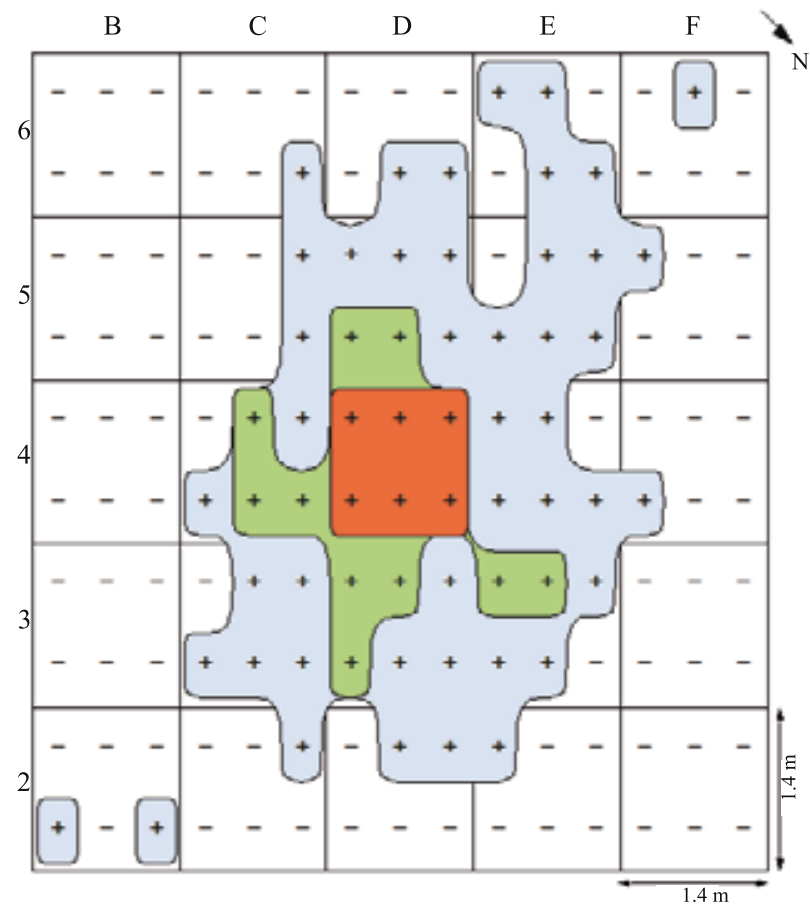

Inoculated mini plot $\bigcirc$ Disease symptoms out of the central contamination focus $\bigcirc$ Contamination without disease symptoms $\bigcirc$ Contamination not detected

Figure 3. Dispersion of halo blight of bean (Phaseolus vulgaris), a disease caused by Pseudomonas savastanoi pv. phaseolicola, from the central contamination focus (miniplot D4), 1 month after inoculation. Only one of the four experimental plots is represented here: plot II of the susceptible Capitole cultivar inoculated with the more aggressive CFBP 4787 strain, at $10^{8} \mathrm{CFU} \mathrm{mL}^{-1}$. 
(Yorinori et al., 1998), the bacteria still represent a major threat to the bean-producing regions in the country. The pathogen's life cycle traits described may support a different decision regarding the quarantine regulation for the bacteria; therefore, the important epiphytic phase of its life cycle remains a trait to be considered. An emerging disease or a disease in its first occurrence, such as halo blight of bean in Brazil, deserves more attention, and one of two procedures should be adopted: either to study the pathosystem thoroughly in the occurrence area in order to understand the reasons for its lack of spread, or to subject bean production regions to a broad survey in order to achieve a reliable diagnosis of the situation. Candidatus Liberibacter solanacearum, for example, an emerging disease in the United States, is being studied in depth, and integrated management strategies are being proposed (Lin \& Gudmestad, 2013). Furthermore, new methods are being developed to facilitate the elaboration of surveys for newly reported pests (Parnell et al., 2014), and analyses on the possibility of outbreaks have been conducted to warn the authorities of the main risks from emerging threats (Janse, 2012). Lately, attention also has been paid to diseases categorized as reemerging. According to Fry et al. (2015), the oomycete Phytophthora infestans, which causes late blight of potato (Solanum tuberosum L.) and has spread worldwide over 150 years, should be considered a reemerging pathogen, for five reasons, among which: the fact that the pathogen continues to appear in unexpected locations or with unpredictable intensity, and that many questions remain unanswered. Scortichini et al. (2012) analyzed a sudden, reemerging worldwide wave of the bacterial canker of kiwifruit [Actinidia deliciosa (A.Chev.) C.F.Liang \& A.R.Ferguson], due to $P$. syringae pv. actinidiae, and suggested that it can be considered a pandemic disease.

\section{Conclusions}

1. The epiphytic life cycle of Pseudomonas savastanoi pv. phaseolicola is clearly detected on the leaves of bean (Phaseolus vulgaris), its host plant, under field and controlled conditions, and the bacterial population sizes may increase significantly without causing the disease.
2. The disease outbreak, originating from a high bacterial population in asymptomatic plants, suggests that rainfall volume and intensity play an important role in driving the bacteria into leaves, which induces the disease.

3. Bacterial asymptomatic dispersion precedes disease symptoms, indicating that solely the presence of symptoms is not good enough as an evaluation parameter for an area to be considered free of the pathogen.

4. Pseudomonas savastanoi pv. phaseolicola should be reevaluated regarding quarantine regulation in Brazil and, under an active official control, should be categorized as a present quarantine pest.

\section{Acknowledgements}

To Christine Bureau, for technical assistance; to Alain Huard and Júlia dos Anjos Marques, for preparing Figure 3.

\section{References}

AKHAVAN, A.; BAHAR, M.; ASKARIAN, H.; LAK, M.R.; NAZEMI, A.; ZAMANI, Z. Bean common bacterial blight: pathogen epiphytic life and effect of irrigation practices. SpringerPlus, v.2, p.1-9, 2013. DOI: 10.1186/2193-1801-2-41.

ARNOLD, D.L.; LOVELL, H.C.; JACKSON, R.W.; MANSFIELD, J.W. Pseudomonas syringae pv. phaseolicola: from 'has bean' to supermodel. Molecular Plant Pathology, v.12, p.617-627, 2011. DOI: $10.1111 /$ j.1364-3703.2010.00697.x.

BAKER, C.M.; CHITRAKAR, R.; OBULAREDDY, N.; PANCHAL, S.; WILLIAMS, P.; MELOTTO, M. Molecular battles between plant and pathogenic bacteria in the phyllosphere. Brazilian Journal of Medical and Biological Research, v.43, p.698-704, 2010. DOI: 10.1590/S0100-879X2010007500060.

BEATTIE, G.A. Water relations in the interaction of foliar bacterial pathogens with plants. Annual Review of Phytopathology, v.49, p.533-555, 2011. DOI: 10.1146/annurev-phyto-073009-114436.

BURKHOLDER, W.H. A new bacterial disease of the bean. Phytopathology, v.16, 915-928. 1926.

DENG, X.; LIANG, H.; CHEN, K.; HE, C.; LAN, L.; TANG, X. Molecular mechanisms of two-component system RhpRS regulating type III secretion system in Pseudomonas syringae. Nucleic Acids Research, v.42, p.11472-11486, 2015. DOI: 10.1093/nar/gku865.

DUNCAN, R.W.; GILBERTSON, R.L.; LEMA, M.; SINGH, S.P. Inheritance of resistance to the widely distributed race 6 of Pseudomonas syringae pv. phaseolicola in common bean pinto US14HBR6. Canadian Journal of Plant Science, v.94, p.923-928, 2014. DOI: $10.4141 /$ cjps2013-320.

Pesq. agropec. bras., Brasília, v.51, n.5, p.623-630, maio. 2016 DOI: $10.1590 / \mathrm{S} 0100-204 \mathrm{X} 2016000500024$ 
FRY, W.E.; BIRCH, P.R.J.; JUDELSON, H.S.; GRÜNWALD, N.J.; DANIES, G.; EVERTS, K.L.; GEVENS, A.J.; GUGINO, B.K.; JOHNSON, D.A.; JOHNSON, S.B.; McGRATH, M.T.; MYERS, K.L.; RISTAINO, J.B.; ROBERTS, P.D.; SECOR, G.; SMART, C.D. Five reasons to consider Phytophthora infestans a reemerging pathogen. Phytopathology, v.105, p.966-981, 2015. DOI: 10.1094/PHYTO-01-15-0005-FI.

HARVESON, R.M.; SCHWARTZ, H.F.; URREA, C.A.; YONTS, C.D. Bacterial wilt of dry-edible beans in the Central High Plains of the U.S.: past, present, and future. Plant Disease, v.99, p.1665-1677, 2015. DOI: 10.1094/PDIS-03-15-0299-FE.

HOLLAWAY, G.J.; BRETAG, T.W.; PRICE, T.V. The epidemiology and management of bacterial blight (Pseudomonas syringae pv. pisi) of field pea (Pisum sativum) in Australia: a review. Australian Journal of Agricultural Research, v.58, p.1086-1099, 2007. DOI: 10.1071/AR06384.

JACQUES, M.-A. The effect of leaf age and position on the dynamics of microbial populations on aerial plant surfaces. In: MORRIS, C.E.; NICOT, P.C.; NGUYEN-THE, C. (Eds.). Aerial plant surface microbiology. New York: Plenum Press, 1996. p.233-248. DOI: 10.1007/978-0-585-34164-4_15.

JANSE, J.D. Bacterial diseases that may or do emerge, with (possible) economic damage for Europe and the Mediterranean basin: notes on epidemiology, risks, prevention and management on first occurrence. Journal of Plant Pathology, v.94, p.S4.5-S4.29, 2012. DOI: 10.4454/JPP.V95I4SUP.001.

LAMICHHANE, J.R.; MESSÉAN, A.; MORRIS, C.E. Insights into epidemiology and control of diseases of annual plants caused by the Pseudomonas syringae species complex. Journal of General Plant Pathology, v.81, p.331-350, 2015. DOI: 10.1007/ s10327-015-0605-z.

LEBEN, C. Epiphytic microorganisms in relation to plant disease. Annual Review of Phytopathology, v.3, p.209-230, 1965. DOI: 10.1146/annurev.py.03.090165.001233.

LEGARD, D.E.; SCHWARTZ, H.F. Sources and management of Pseudomonas syringae pv. phaseolicola and Pseudomonas syringae pv. syringae epiphytes on dry beans in Colorado. Phytopathology, v.77, p.1503-1509, 1987. DOI: 10.1094/Phyto-77-1503.

LIN, H.; GUDMESTAD, N.C. Aspects of pathogen genomics, diversity, epidemiology, vector dynamics, and disease management for a newly emerged disease of potato: zebra chip. Phytopathology, v.103, p.524-537, 2013. DOI: 10.1094/ PHYTO-09-12-0238-RVW.

LOVELL, H.C.; JACKSON, R.W.; MANSFIELD, J.W.; GODFREY, S.A.C.; HANCOCK, J.T.; DESIKAN, R.; ARNOLD, D.L. In planta conditions induce genomic changes in Pseudomonas syringae pv. phaseolicola. Molecular Plant Pathology, v.12, p.167-176, 2011. DOI: 10.1111/j.1364-3703.2010.00658.x.

MABAGALA, R.B.; SAETTLER, A.W. Pseudomonas syringae pv. phaseolicola populations and halo blight severity in beans grown alone or intercropped with maize in Northern
Tanzania. Plant Disease, v.76, p.687-692, 1992. DOI: 10.1094/ PD-76-0687.

MARCUZZO, L.L. Importância das populações epifíticas na epidemiologia de enfermidades bacterianas. Revista de Ciências Agroveterinárias, v.8, p.146-151, 2009.

MELOTTO, M.; UNDERWOOD, W.; HE, S.Y. Role of stomata in plant innate immunity and foliar bacterial diseases. Annual Review of Phytopathology, v.46, p.101-122, 2008. DOI: 10.1146/ annurev.phyto.121107.104959.

PARNELL, S.; GOTTWALD, T.R.; RILEY, T.; BOSCH, F. van den. A generic risk-based surveying method for invading plant pathogens. Ecological Applications, v.24, p.779-790, 2014. DOI: 10.1890/13-0704.1.

PAUWELYN, E.; VANHOUTEGHEM, K.; COTTYN, B.; DE VOS, P.; MAES, M.; BLEYAERT, P.; HÖFTE, M. Epidemiology of Pseudomonas cichorii, the cause of lettuce midrib rot. Journal of Phytopathology, v.159, p.298-305, 2011. DOI: 10.1111/j.1439 $-0434.2010 .01764 . \mathrm{x}$

PIETRARELLI, L.; BALESTRA, G.M.; VARVARO, L. Effects of simulated rain on Pseudomonas syringae pv. tomato populations on tomato plants. Journal of Plant Pathology, v.88, p.245-251, 2006.

SCHAAD, N.W.; BERTHIER-SCHAAD, Y.; KNORR, D. A high throughput membrane BIO-PCR technique for ultra-sensitive detection of Pseudomonas syringae pv. phaseolicola. Plant Pathology, v.56, p.1-8, 2007. DOI: 10.1111/j.1365-3059.2006.01488.x.

SCHAAD, N.W.; JONES, J.B.; CHUN, W. Laboratory guide for identification of plant pathogenic bacteria. $3^{\text {rd }}$ ed. St. Paul: American Phytopathological Society, 2001. 373p.

SCORTICHINI, M.; MARCELLETTI, S.; FERRANTE, P.; PETRICCIONE, M.; FIRRAO, G. Pseudomonas syringae pv. actinidiae: a re-emerging, multi-faceted, pandemic pathogen. Molecular Plant Pathology, v.13, p.631-640, 2012. DOI: 10.1111/j.1364-3703.2012.00788.x.

TAYLOR, J.D.; DUDLEY, C.L.; PRESLY, L. Studies of halo-blight seed infection disease transmission in dwarf beans. Annals of Applied Biology, v.93, p.267-277, 1979. DOI: 10.1111/ j.1744-7348.1979.tb06541.x.

WALKER, J.C.; PATEL, P.N. Splash dispersal and wind as factors in epidemiology of halo blight of bean. Phytopathology, v.54, p.140-141, 1964.

YORINORI, M.A.; FUNADA, C.K.; RODRIGUES; B.A.; LEITE JR., R.P.; UENO, B. Ocorrência do crestamento bacteriano aureolado do feijoeiro causado por Pseudomonas syringae pv. phaseolicola no Estado do Paraná. Fitopatologia Brasileira, v.23, p.218, 1998.

YOSHIDA, S.; KINKEL, L.L.; SHINOHARA, H.; NUMAJIRI, N.; HIRADATE, S.; KOITABASHI, M.; SUYAMA, K.; NEGISHI, H.; TSUSHIMA, S. Production of quorum-sensing-related signal molecules by epiphytic bacteria inhabiting wheat heads. Canadian Journal of Microbiology, v.52, p.411-418, 2006. DOI: 10.1139/ w05-146.

Received on December 23, 2014 and accepted on March 4, 2016

Pesq. agropec. bras., Brasília, v.51, n.5, p.623-630, maio 2016 DOI: 10.1590/S0100-204X2016000500024 